\title{
Does leptin predict successful induction of labor?
}

\author{
Whitney Cowman, MD, ${ }^{1}$ Sabrina Scroggins, $\mathrm{PhD},{ }^{1}$ Wendy Hamilton, ${ }^{1}$ Brenda Boese, ${ }^{1}$
} Noelle Bowdler, MD ${ }^{1}$ Eric Devor, $\mathrm{PhD},{ }^{1}$ Mark Santillan, MD ${ }^{1}$ Donna Santillan, $\mathrm{PhD}^{1}$

Keywords: Obesity, induction of labor, leptin

\section{Objective}

Obesity in pregnancy is becoming increasingly common and is associated with many pregnancy-related complications such as failed induction of labor (IOL). Leptin, an adipocytokine important in energy homeostasis, is found in higher levels in obese individuals. Leptin has also been demonstrated to have an inhibitory effect on myometrial contractility in vitro. We hypothesize that leptin may play a part in the mechanism of dysfunctional labor. Thus, we sought to compare the maternal plasma leptin levels in women that had a successful vaginal delivery post-IOL vs. those who had a C-section post-IOL.

\section{Study Design}

This was a retrospective case-control study utilizing the University of Iowa
IRB-approved Maternal-Fetal Tissue Bank (MFTB) (IRB\#200910784). A total of 168 women underwent induction of labor, with 54 ultimately delivering via Cesarean section compared to 114 women who had successful IOL and delivered vaginally. Information on maternal/neonatal characteristics was collected from the MFTB secure database and verified in the electronic medical record. Leptin levels were measured using the commercially available Human Leptin Instant Elisa (eBioscience). BCA levels were measured using a commercially BCA Protein Assay Kit (Thermo Scientific), for the quantification of total protein for normalization. All statistical analyses were performed with SigmaPlot 12.0 software (Systat Software, Inc, California) and confirmed using SAS 9.1 software (SAS Institute Inc, Cary, NC). Logistic regression models were constructed using regression identified

${ }^{1}$ Department of Obstetrics and Gynecology, Carver College of Medicine, University of lowa Hospitals and Clinics, lowa City, IA, 52242

Please cite this abstract as: Cowman W, Scroggins S, Hamilton W, Boese B, Bowdler N, Devor E, Santillan M, Santillan D. Does leptin predict successful induction of labor? Proc Obstet Gynecol. 2015;5(3):Article 7 [ 2 p.]. Available from: http://ir.uiowa.edu/pog/ Free full text article.

Corresponding author: Whitney Cowman, Department of Obstetrics and Gynecology, University of lowa, 200 Hawkins Drive, lowa City, IA 42242, whitney-cowman@uiowa.edu

Copyright: (c) 2015 Cowman, et al. This is an open-access article distributed under the terms of the Creative Commons Attribution License, which permits unrestricted use, distribution, and reproduction in any medium, provided the original author and source are credited. 
and clinically significant confounding variables. In addition, chi square analyses were utilized for categorical variables. For continuous variables, the Student's t-test or ANOVA was utilized. All variables were tested at significance level of 0.05 .

\section{Results}

Maternal serum leptin levels were not statistically significantly different between women with successful IOL: $25525 \mathrm{pg} / \mathrm{mL}$ vs failed IOL: 34009 $\mathrm{pg} / \mathrm{mL}, \mathrm{P}=0.102$ ). However, once leptin levels were normalized for total protein (leptin/protein [picogram/microgram]), women with failed IOL had higher values (0.5 vs 0.3 , $\mathrm{P}=0.01)$. Women with failed $\mathrm{IOL}$ were more likely to have obesity (mean BMI 32 vs $27, P=0.0002$ ), preeclampsia (13\% vs $2 \%, P=0.008)$, lower Bishop score ( 3 vs $5, P<0.001$ ), lower parity ( 0.3 vs $0.9, \mathrm{P}<0.001)$ and meconiumstained fluid (35\% vs $13 \%, P=0.002)$. Method(s) of induction of labor in women with failed IOL, was/were more likely to include dinoprostone ( $65 \%$ vs $29 \%, \mathrm{P}<0.001)$ and Foley balloon placement $(26 \%$ vs $11 \%, P=0.03)$. They were also more likely to require multiple induction methods as defined by use of two or more methods (93\% vs $73 \%, P=0.008$ ). In a multivariate regression model, Bishop score was the only covariate associated with successful IOL (OR 1.5, P $<0.001$ ). BMI (OR 0.92, $\mathrm{P}<0.001$ ), preeclampsia (0.12, $\mathrm{P}=0.010)$, use of multiple methods of induction (OR 0.22, $\mathrm{P}=$ 0.008 ) and leptin/protein (OR 0.42, $\mathrm{P}=$ 0.017 ) were all associated with failed IOL. After controlling for Bishop score and preeclampsia, leptin/protein $(\mathrm{pg} / \mathrm{mcg})$ was still significantly associated with a decreased likelihood of successful induction of labor with an odds ratio of $0.47(P=0.046)$.

\section{Conclusion}

Higher leptin/protein levels are predictive of failed IOL with an odds ratio of $0.47(P=0.046)$, for successful IOL. Our data support the hypothesis that leptin is an important factor in explaining why obese women are more likely to have dysfunctional labor and failed induction of labor.

Presented at "Practical Update in Ob/Gyn," the University of lowa Obstetrics and Gynecology Postgraduate conference, 2 October 2015, hotelVetro \& Conference Center, lowa City, lowa 52240. 